\title{
Affected Twins in the Familial Intracranial Aneurysm Study
}

\author{
Jason Mackey ${ }^{\mathrm{a}}$ Robert D. Brown ${ }^{\mathrm{b}}$ Laura Sauerbeck ${ }^{c}$ Richard Hornung ${ }^{d}$ \\ Charles J. Moomawc Daniel L. Kollere Tatiana Foroud ${ }^{\mathrm{c}}$ Ranjan Deka $^{\mathrm{f}}$ \\ Daniel Woo ${ }^{c}$ Dawn Kleindorfer ${ }^{c}$ Matthew L. Flaherty ${ }^{c}$ Irene Meissner ${ }^{b}$ \\ Craig Anderson ${ }^{g}$ Guy Rouleau ${ }^{h}$ E. Sander Connolly ${ }^{i}$ John Huston ${ }^{j}$ \\ Joseph P. Broderick ${ }^{c}$ for the FIA Investigators
}

\begin{abstract}
${ }^{a}$ Department of Neurology, Indiana University, Indianapolis, Ind., bepartment of Neurology, Mayo Clinic, Rochester, Minn., ' Department of Neurology, University of Cincinnati and d Department of Emergency Medicine, Cincinnati Children's Hospital Medical Center, Cincinnati, Ohio, e'Department of Medical \& Molecular Genetics, Indiana University,

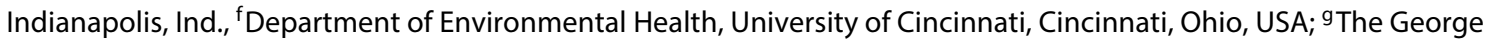
Institute for International Health, University of Sydney, Sydney, Australia; ${ }^{\mathrm{h}}$ Notre Dame Hospital, University of Montreal, Montreal, Canada; 'Department of Neurosurgery, Columbia University, New York, N.Y. and 'Department of Radiology, Mayo Clinic, Rochester, Minn., USA
\end{abstract}

\section{Key Words}

Intracranial aneurysm · Genetics · Twins · Familial ·

Concordance

\begin{abstract}
Background and Purpose: Very few cases of intracranial aneurysms (IAs) in twins have been reported. Previous work has suggested that vulnerability to IA formation is heritable. Twin studies provide an opportunity to evaluate the impact of genetics on IA characteristics, including IA location. We therefore sought to examine IA location concordance, multiplicity, and rupture status within affected twin-pairs. Methods: The Familial Intracranial Aneurysm study was a multicenter study whose goal was to identify genetic and other risk factors for formation and rupture of IAs. The study required at least three affected family members or an affected sibling pair for inclusion. Subjects with fusiform aneurysms, an IA associated with an AVM, or a family history of conditions known to predispose to IA formation, such as polycys-
\end{abstract}

tic kidney disease, Ehlers-Danlos syndrome, Marfan syndrome, fibromuscular dysplasia, or moyamoya syndrome were excluded. Twin-pairs were identified by birth date and were classified as monozygotic (MZ) or dizygotic (DZ) through DNA marker genotypes. In addition to zygosity, we evaluated twin-pairs by smoking status, major arterial territory of IAs, and rupture status. Location concordance was defined as the presence of an IA in the same arterial distribution (ICA, MCA, ACA, and vertebrobasilar), irrespective of laterality, in both members of a twin-pair. The Fisher exact test was used for comparisons between $\mathrm{MZ}$ and $\mathrm{DZ}$ twin-pairs. Results: A total of 16 affected twin-pairs were identified. Location concordance was observed in 8 of $11 \mathrm{MZ}$ twin-pairs but in only 1 of $5 \mathrm{DZ}$ twin-pairs ( $p=0.08$ ). Three MZ subjects had unknown IA locations and comprised the three instances of $M Z$ discordance. Six of the $11 \mathrm{MZ}$ twin-pairs and none of the $5 \mathrm{DZ}$ twin-pairs had IAs in the ICA distribution ( $p=$

Statistical analysis: Richard Hornung, DrPH.

\section{KARGER 125}

(c) 2015 S. Karger AG, Basel

1015-9770/15/0392-0082\$39.50/0

E-Mail karger@karger.com

www.karger.com/ced
Jason Mackey, MD, MS

Department of Neurology, Indiana University

355 West 16th St., Suite 3200

Indianapolis, IN 46202 (USA)

E-Mail jsmackey@iupui.edu 
0.03). Multiple IAs were observed in 11 of $22 \mathrm{MZ}$ and 5 of 10 DZ twin-pairs. Thirteen (13) of the 32 subjects had an IA rupture, including 10 of $22 \mathrm{MZ}$ twins. Conclusions: We found that arterial location concordance was greater in $M Z$ than DZ twins, which suggests a genetic influence upon aneurysm location. The 16 twin-pairs in the present study are nearly the total of affected twin-pairs that have been reported in the literature to date. Further studies are needed to determine the impact of genetics in the formation and rupture of IAs.

(c) 2015 S. Karger AG, Basel

\section{Introduction}

Genetic and environmental factors have been implicated in intracranial aneurysm (IA) formation [1]. Previous work has suggested that vulnerability to IA formation is heritable [2,3]. Twin studies provide an opportunity to evaluate the impact of genetics on IA characteristics, including IA location. A few cases of IAs in twins have been reported in the literature [4], and risk factor profiles and other clinical characteristics are often absent in these reports. While genetic SAHs appear rare [5, 6], an understanding of the genetic contributions to IA formation and rupture may help improve the understanding of the underlying pathophysiology and stratify risk. We sought to examine the similarity of IA location ('location concordance'), IA multiplicity, and rupture status within affected twin-pairs in a large family based IA study.

\section{Methods}

The Familial Intracranial Aneurysm (FIA) study was a multicenter international study whose goal was to identify genetic and other risk factors for IA formation and rupture. The FIA study was approved by the Institutional Review Boards/Ethics Committees of all recruitment and analytic sites.

The detailed FIA study methodology has been published previously [7]. Families with multiple affected members were enrolled and completed a detailed evaluation. At least three affected family members or an affected sibling pair were required for inclusion in the study. Subjects with fusiform aneurysms, an IA associated with an AVM, or a family history of conditions known to predispose to IA formation, such as polycystic kidney disease, Ehlers-Danlos syndrome, Marfan syndrome, fibromuscular dysplasia, or moyamoya syndrome, were excluded.

A verification committee of study neurologists reviewed the medical records. Two study neurologists independently reviewed the records and any discrepancy was settled by a third neurologist. For those subjects undergoing FIA study imaging, study neuroradiologists independently reviewed the images and any discrepancy

Familial Aneurysms in Twins was resolved by a third neuroradiologist. Each case was phenotyped as definite, probable, possible, or not a case. Definite was defined as an IA on angiography, operative report, autopsy, or an IA greater than $7 \mathrm{~mm}$ on a noninvasive imaging report (MRA or CTA). Probable was defined as a death certificate mentioning probable IA or mentioning subarachnoid hemorrhage (SAH) without an aneurysm and a phone screen consistent with a ruptured IA, or noninvasive imaging demonstrating an IA less than $7 \mathrm{~mm}$ but greater than $3 \mathrm{~mm}$. Possible was defined as noninvasive imaging demonstrating an IA between 2 and $3 \mathrm{~mm}$ or if SAH was documented in the death certificate without any supporting documentation or if the death certificate listed 'aneurysm' without specifying cerebral location or an accompanying SAH. If there was no evidence for a possible IA, the phenotype was not a case.

Twin-pairs were identified in the database by birth date. Genotypic data were used to classify twin-pairs as monozygotic (MZ) or dizygotic (DZ) [8]. The present analysis included twin-pairs in which both twins were affected with IA. Demographics were recorded at the baseline interview. IA characteristics were recorded from available imaging and medical record reports.

Location concordance was defined as the presence of an IA in the same major arterial territory - internal carotid artery (ICA), middle cerebral artery (MCA), anterior cerebral artery (ACA), or vertebrobasilar - irrespective of laterality - in both members of a twin-pair. Fisher's exact test was used to test whether concordance was greater in $\mathrm{MZ}$ as compared with $\mathrm{DZ}$ twin-pairs.

\section{Results}

Using birthdates and linkage testing, we identified 36 candidate families in the overall FIA study with twins. One family with three twins (two MZ siblings and one DZ sibling) was excluded because all three siblings were unaffected. Seven twin-pairs (two MZ, five DZ) were excluded because both twins were unaffected. Five twin-pairs (one MZ, four DZ) were excluded because only one twin was affected. Six twin-pairs (two MZ, four DZ) were excluded because one twin was affected but the other twin refused a study MRA. One twin-pair (DZ) was excluded because one twin was unaffected and the other twin refused a study MRA. A total of 16 affected twin-pairs met inclusion criteria for this study. All included subjects had a definite or probable phenotype with the exception of one twin in the $5 \mathrm{DZ}$ twin-pair. Patient and IA characteristics are noted in the table 1. Location concordance was observed in 8 of $11 \mathrm{MZ}$ twin-pairs but only in 1 of $5 \mathrm{DZ}$ twinpairs $(\mathrm{p}=0.08)$. Three MZ subjects had unknown IA locations; these comprised the three instances of MZ discordance. Data from twins with conclusive location results in a heritability estimate of $66 \%$. Seven of the 11 $\mathrm{MZ}$ twin-pairs versus none of the five $\mathrm{DZ}$ twin-pairs, were concordant in the ICA distribution $(p=0.03)$. Five of the $11 \mathrm{MZ}$ twin-pairs versus one of the five $\mathrm{DZ}$ twin- 
Table 1. Characteristics of monozygotic (MZ) and dizygotic (DZ) twin-pairs at time of initial diagnosis of intracranial aneurysm (IA)

\begin{tabular}{|c|c|c|c|c|c|}
\hline Age & Gender & $\mathrm{HTN}$ & $\begin{array}{l}\text { Smoking } \\
\text { (pack-years) }\end{array}$ & IA location(s) and size & Rupture \\
\hline
\end{tabular}

MZ twin-pairs

\begin{tabular}{|c|c|c|c|c|c|c|}
\hline 1 & $\begin{array}{l}22 \\
22\end{array}$ & $\begin{array}{l}\mathrm{F} \\
\mathrm{F}\end{array}$ & $\begin{array}{l}\text { no } \\
\text { no }\end{array}$ & $\begin{array}{l}\text { never } \\
\text { never }\end{array}$ & $\begin{array}{l}\text { L ICA (unk), R ICA (6 mm) } \\
\text { L ICA (unk), AComm (unk) }\end{array}$ & $\begin{array}{l}\text { yes (L ICA) } \\
\text { yes (L ICA) }\end{array}$ \\
\hline 2 & $\begin{array}{l}56 \\
55\end{array}$ & $\begin{array}{l}\mathrm{F} \\
\mathrm{F}\end{array}$ & $\begin{array}{l}\text { no } \\
\text { yes }\end{array}$ & $\begin{array}{l}\text { former }(43.5) \\
\text { former }(3.6)\end{array}$ & $\begin{array}{l}\text { L MCA (6 mm), L AntChor (unk), Bas (unk), } \\
\text { L SupHyp ( } 3 \mathrm{~mm}) \\
\text { L ICA }(3 \mathrm{~mm})\end{array}$ & $\begin{array}{l}\text { yes (record does } \\
\text { not indicate } \\
\text { which IA) } \\
\text { no }\end{array}$ \\
\hline 3 & $\begin{array}{l}43 \\
43\end{array}$ & $\begin{array}{l}\mathrm{F} \\
\mathrm{F}\end{array}$ & $\begin{array}{l}\text { no } \\
\text { no }\end{array}$ & $\begin{array}{l}\text { current }(14.5) \\
\text { current }(21.8)\end{array}$ & $\begin{array}{l}\text { L ICA }(7 \mathrm{~mm}), \mathrm{L} \text { Ophth }(1.5 \mathrm{~mm}) \\
\text { not specified on report }\end{array}$ & $\begin{array}{l}\text { no } \\
\text { yes }\end{array}$ \\
\hline 4 & $\begin{array}{l}41 \\
27\end{array}$ & $\begin{array}{l}\mathrm{M} \\
\mathrm{M}\end{array}$ & $\begin{array}{l}\text { yes } \\
\text { no }\end{array}$ & $\begin{array}{l}\text { never } \\
\text { never }\end{array}$ & $\begin{array}{l}\text { R ICA }(3 \mathrm{~mm}) \\
\text { R ICA }(6 \mathrm{~mm})\end{array}$ & $\begin{array}{l}\text { no } \\
\text { yes }\end{array}$ \\
\hline 5 & $\begin{array}{l}32 \\
31\end{array}$ & $\begin{array}{l}\mathrm{F} \\
\mathrm{F}\end{array}$ & $\begin{array}{l}\text { no } \\
\text { yes }\end{array}$ & $\begin{array}{l}\text { current }(14.3) \\
\text { current }(18)\end{array}$ & $\begin{array}{l}\text { R MCA (unk), L MCA (unk) } \\
\text { not specified on report }\end{array}$ & $\begin{array}{l}\text { no } \\
\text { yes }\end{array}$ \\
\hline 6 & $\begin{array}{l}51 \\
53\end{array}$ & $\begin{array}{l}\mathrm{F} \\
\mathrm{F}\end{array}$ & $\begin{array}{l}\text { yes } \\
\text { yes }\end{array}$ & $\begin{array}{l}\text { never } \\
\text { never }\end{array}$ & $\begin{array}{l}\operatorname{AComm}(7 \mathrm{~mm}) \\
\operatorname{AComm}(4 \mathrm{~mm})\end{array}$ & $\begin{array}{l}\text { yes } \\
\text { yes }\end{array}$ \\
\hline 7 & $\begin{array}{l}54 \\
53\end{array}$ & $\begin{array}{l}M \\
M\end{array}$ & $\begin{array}{l}\text { no } \\
\text { no }\end{array}$ & $\begin{array}{l}\text { former }(25.1) \\
\text { current }(21)\end{array}$ & $\begin{array}{l}\text { R ICA }(7 \mathrm{~mm}) \text {, L SupCer }(3 \mathrm{~mm}) \\
\text { L MCA (17 mm), R PComm }(5 \mathrm{~mm}) \text {, AComm (unk) }\end{array}$ & $\begin{array}{l}\text { no } \\
\text { no }\end{array}$ \\
\hline 8 & $\begin{array}{l}56 \\
56\end{array}$ & $\begin{array}{l}\mathrm{F} \\
\mathrm{F}\end{array}$ & $\begin{array}{l}\text { no } \\
\text { no }\end{array}$ & $\begin{array}{l}\text { never } \\
\text { never }\end{array}$ & $\begin{array}{l}\text { R ICA }(8 \mathrm{~mm}) \text {, Bas }(3 \mathrm{~mm}) \\
\text { L ICA (unk) }\end{array}$ & $\begin{array}{l}\text { no } \\
\text { no }\end{array}$ \\
\hline 9 & $\begin{array}{l}45 \\
44\end{array}$ & $\begin{array}{l}\mathrm{F} \\
\mathrm{F}\end{array}$ & $\begin{array}{l}\text { no } \\
\text { no }\end{array}$ & $\begin{array}{l}\text { current }(20.3) \\
\text { current }(11)\end{array}$ & $\begin{array}{l}\text { R MCA (unk), R PComm (unk), AntChor (unk) } \\
\text { R PComm (11 mm) }\end{array}$ & $\begin{array}{l}\text { yes (R MCA) } \\
\text { no }\end{array}$ \\
\hline 10 & $\begin{array}{l}68 \\
66\end{array}$ & $\begin{array}{l}\mathrm{F} \\
\mathrm{F}\end{array}$ & $\begin{array}{l}\text { no } \\
\text { no }\end{array}$ & $\begin{array}{l}\text { former }(14) \\
\text { former }(34)\end{array}$ & $\begin{array}{l}\text { L ICA (unk), L MCA (unk) } \\
\text { L MCA ( } 5 \text { mm), L ICA ( } 2 \text { mm) }\end{array}$ & $\begin{array}{l}\text { no } \\
\text { no }\end{array}$ \\
\hline 11 & $\begin{array}{l}50 \\
42\end{array}$ & $\begin{array}{l}\mathrm{F} \\
\mathrm{F}\end{array}$ & $\begin{array}{l}\text { no } \\
\text { no }\end{array}$ & $\begin{array}{l}\text { current }(17) \\
\text { current }(20.3)\end{array}$ & $\begin{array}{l}\text { MCA (report does not mention side or size) } \\
\text { not specified on death certificate (unk) }\end{array}$ & $\begin{array}{l}\text { no } \\
\text { yes }\end{array}$ \\
\hline $\mathrm{D}^{\prime}$ & vin-1 & & & & & \\
\hline 1 & $\begin{array}{l}64 \\
64\end{array}$ & $\begin{array}{l}\mathrm{F} \\
\mathrm{F}\end{array}$ & $\begin{array}{l}\text { no } \\
\text { yes }\end{array}$ & $\begin{array}{l}\text { never } \\
\text { current (43) }\end{array}$ & $\begin{array}{l}\text { R ICA }(4.5 \mathrm{~mm}) \\
\mathrm{L} \text { MCA }(2 \mathrm{~mm})\end{array}$ & $\begin{array}{l}\text { no } \\
\text { no }\end{array}$ \\
\hline 2 & $\begin{array}{l}61 \\
60\end{array}$ & $\begin{array}{l}\mathrm{F} \\
\mathrm{F}\end{array}$ & $\begin{array}{l}\text { yes } \\
\text { yes }\end{array}$ & $\begin{array}{l}\text { former }(8.7) \\
\text { never }\end{array}$ & $\begin{array}{l}\text { R ICA }(8 \mathrm{~mm}), \mathrm{R} \text { ICA }(1 \mathrm{~mm}) \\
\mathrm{AComm}(15 \mathrm{~mm})\end{array}$ & $\begin{array}{l}\text { no } \\
\text { yes }\end{array}$ \\
\hline 3 & $\begin{array}{l}46 \\
46\end{array}$ & $\begin{array}{l}\mathrm{F} \\
\mathrm{F}\end{array}$ & $\begin{array}{l}\text { no } \\
\text { no }\end{array}$ & $\begin{array}{l}\text { former }(16.5) \\
\text { former }(5.8)\end{array}$ & $\begin{array}{l}\text { L MCA }(4 \mathrm{~mm}) \text {, Bas }(3 \mathrm{~mm}) \\
\text { R MCA }(7 \mathrm{~mm}) \text {, R ACA }(2.9 \mathrm{~mm}) \text {, Bas }(0.5 \mathrm{~mm})\end{array}$ & $\begin{array}{l}\text { yes (Bas) } \\
\text { no }\end{array}$ \\
\hline 4 & $\begin{array}{l}44 \\
35\end{array}$ & $\begin{array}{l}\mathrm{F} \\
\mathrm{F}\end{array}$ & $\begin{array}{l}\text { no } \\
\text { no }\end{array}$ & $\begin{array}{l}\text { former }(2) \\
\text { current }(20)\end{array}$ & $\begin{array}{l}\text { AComm (unk) } \\
\text { L MCA (unk) }\end{array}$ & $\begin{array}{l}\text { no } \\
\text { yes }\end{array}$ \\
\hline 5 & $\begin{array}{l}51 \\
51\end{array}$ & $\begin{array}{l}\mathrm{F} \\
\mathrm{F}\end{array}$ & $\begin{array}{l}\text { no } \\
\text { yes }\end{array}$ & $\begin{array}{l}\text { former }(17.8) \\
\text { current }(34)\end{array}$ & $\begin{array}{l}\text { L MCA }(6 \mathrm{~mm}), \text { R MCA }(2 \mathrm{~mm}) \\
\text { AComm }(3 \mathrm{~mm}), \text { L PComm }(3 \mathrm{~mm})\end{array}$ & $\begin{array}{l}\text { no } \\
\text { no }\end{array}$ \\
\hline
\end{tabular}

IAs in bold type denote location concordance within twin-pairs.

ICA territory: ICA = Internal carotid artery; PComm = posterior communicating artery; Ophth = ophthalmic artery; AntChor = anterior choroidal artery; SupHyp = superior hypophyseal artery.

MCA territory: MCA = Middle cerebral artery.

ACA territory: $\mathrm{ACA}=$ Anterior cerebral artery; $\mathrm{AComm}=$ anterior communicating artery.

Vertebrobasilar territory: Bas = Basilar tip; SupCer = superior cerebellar artery.

CTA = CT angiogram; unk = unknown. 
pairs, had exact matches of IA location and laterality. Age, gender, hypertensive status, smoking behavior, IA location and size, and rupture status of affected twins are shown in the table 1.

\section{Discussion}

We found that location concordance was greater in $\mathrm{MZ}$ than DZ twins in twin-pairs in which both twins are affected. Our previous work has demonstrated that IA location concordance is greater in several territories when probands are compared with their own affected first-degree relatives than with a randomly selected comparison family, which suggests that anatomic vulnerability might be heritable. The present paper extends this work by comparing the $\mathrm{MZ}$ and $\mathrm{DZ}$ twins.

Efforts to identify genes associated with IA formation have been modestly successful. Genome-wide association studies have demonstrated associations between multiple loci and IA formation [8-15], although the effect sizes of these common SNPs are modest. This suggests that there are likely many common variants of modest effect contributing to IA risk. These studies did not stratify by IA location.

Very few affected IA twin pairs have been reported in the literature $[4,5,16]$, with high location concordance rates in those studies, which report IA locations. Most affected twin-pairs have both suffered an SAH. A study of the Nordic Twin Cohort found 6 instances (5 MZ) of concordant SAH in nearly 80,000 twin-pairs, of which 30\% were MZ. IA locations were not reported [5]. The reasons why so few cases have been reported are unclear.

The 16 twin-pairs in the present study are nearly the total of affected twin-pairs that have been reported in the literature to date, with the advantages of genetic confirmation of zygosity and risk factor profiles. However, this study has several limitations: it is small and IA locations were unknown for three MZ twins. The small sample size also limits our ability to comment on the contribution of environmental risk factors such as smoking on IA formation. Because this was a cross-sectional study and IA can develop over time, we only included twin-pairs with both twins affected; this limits the analysis of genetic contribution to IA location. In addition, phenotype verification in the FIA study was largely based on reports rather than images, so that independent verification of IA location by the study team was not possible. We cannot comment on IA development over time. We also cannot comment on IA anatomic or hemodynamic characteristics.

IA formation is a complex process. An improved understanding of the genetic component of IA formation could result in improved identification of at-risk individuals.

\section{Acknowledgments}

We would like to thank the subjects and their families for their participation.

\section{Sources of Funding}

This study was funded by NIH R01NS39512.

\section{Disclosure Statements}

Dr. Broderick is the PI of NIH R01NS39512. Dr. Brown is the PI of NIH R01NS028492 and is supported by NS39512. Dr. Anderson reports employment with the George Institute for Global Health and the National Health and Medical Research Council of Australia. Dr. Woo is supported by NS36695, NS69208, and NS69763. L. Sauerbeck and Drs. Moomaw, Foroud, Hornung, and Deka are supported by NS39512. The other authors report no conflicts.

\section{References}

1 Ruigrok YM, Rinkel GJ: Genetics of intracranial aneurysms. Stroke 2008;39:1049-1055.

-2 Mackey J, Brown RD Jr, Moomaw CJ, Hornung R, Sauerbeck L, Woo D, et al: Familial intracranial aneurysms: is anatomic vulnerability heritable? Stroke 2013;44:38-42

-3 Mackey J, Brown RD Jr, Moomaw CJ, Sauerbeck L, Hornung R, Gandhi D, et al: Unruptured intracranial aneurysms in the familial intracranial aneurysm and international study of unruptured intracranial aneurysms cohorts: differences in multiplicity and location. J Neurosurg 2012;117:60-64.

ter Laan M, Kerstjens-Frederikse WS, Metzemaekers JD, van Dijk JM, Groen RJ: Concordant symptomatic intracranial aneurysm in a monozygotic twin: a case report and review of the literature. Twin Res Hum Genet 2009; 12:295-300.

Korja M, Silventoinen K, McCarron $\mathrm{P}$, Zdravkovic S, Skytthe A, Haapanen A, et al: Genetic epidemiology of spontaneous sub- arachnoid hemorrhage: Nordic Twin Study. Stroke 2010;41:2458-2462.

6 6 Bor AS, Rinkel GJ, Adami J, Koffijberg H, Ekbom A, Buskens E, et al: Risk of subarachnoid haemorrhage according to number of affected relatives: a population based case-control study. Brain 2008;131:2662-2665.

7 Broderick JP, Sauerbeck LR, Foroud T, Huston J 3rd, Pankratz N, Meissner I, et al: The Familial Intracranial Aneurysm (FIA) study protocol. BMC Medical Genetics 2005;6:17. 
$>8$ Foroud T, Sauerbeck L, Brown R, Anderson C, Woo D, Kleindorfer D, et al: Genome screen in familial intracranial aneurysm. BMC Med Genet 2009;10:3.

-9 Deka R, Koller DL, Lai D, Indugula SR, Sun G, Woo D, et al: The relationship between smoking and replicated sequence variants on chromosomes 8 and 9 with familial intracranial aneurysm. Stroke 2010;41:1132-1137.

10 Bilguvar K, Yasuno K, Niemelä M, Ruigrok YM, von Und Zu Fraunberg M, van Duijn CM, et al: Susceptibility loci for intracranial aneurysm in European and Japanese populations. Nat Genet 2008;40:1472-1477.

-11 Yasuno K, Bilguvar K, Bijlenga P, Low SK, Krischek B, Auburger G, et al: Genome-wide association study of intracranial aneurysm identifies three new risk loci. Nat Genet 2010;42:420-425.
12 Yasuno K, Bakırcıoğlu M, Low SK, Bilgüvar K, Gaál E, Ruigrok YM, et al: Common variant near the endothelin receptor type $\mathrm{A}$ (EDNRA) gene is associated with intracranial aneurysm risk. Proc Natl Acad Sci U S A 2011;108:19707-19712.

13 Foroud T, Koller DL, Lai D, Sauerbeck L, Anderson C, Ko N, et al: Genome-wide association study of intracranial aneurysms confirms role of Anril and SOX17 in disease risk. Stroke 2012;43:2846-2852.
4 Low SK, Takahashi A, Cha PC, Zembutsu H, Kamatani N, Kubo M, et al: Genome-wide association study for intracranial aneurysm in the Japanese population identifies three candidate susceptible loci and a functional genetic variant at EDNRA. Hum Mol Genet 2012;21:2102-2110.

15 Hashikata H, Liu W, Inoue K, Mineharu Y, Yamada S, Nanayakkara S, et al: Confirmation of an association of single-nucleotide polymorphism rs1333040 on 9p21 with familial and sporadic intracranial aneurysms in Japanese patients. Stroke 2010;41:11381144.

16 Leung HK, Lam Y, Cheng KM, Chan CM, Cheung YL: Intracranial aneurysms in twins: case report and review of the literature. Hong Kong Med J 2011;17:151-154. 